\section{Geochemical and isotopic characterization of Mesoarchean metavolcanics from Kurrat-Badwar- Girar Greenstone Belt, southern Bundelkhand Craton, India}

\author{
SIKHA HILOIDARI ${ }^{1,2}$, MANAVALAN \\ SATYANARAYANAN ${ }^{3}$, SURYA PRATAP SINGH ${ }^{4}$, \\ D.SRINIVASA SARMA ${ }^{2,3}$ AND K.S.V. SUBRAMANYAM ${ }^{3}$ \\ ${ }^{1}$ CSIR- National Geophysical Research Institute \\ ${ }^{2}$ Academy of Scientific and Innovative Research (AcSIR), CSIR- \\ National Geophysical Research Institute, Uppal Road, \\ Hyderabad, India -500007 \\ ${ }^{3}$ CSIR-National Geophysical Research Institute \\ ${ }^{4}$ Bundelkhand University \\ Presenting Author: sikha.hiloidari88@gmail.com
}

The metavolcanic rocks from Kurrat-Badwar-Girar Greenstone belt in southern Bundelkhand Craton, India provides evidence for Mesoarchean mafic magmatism. Both pillowed and massive metavolcanics are seen in the greenstone belt and have undergone lower greenschist to lower amphibolite facies metamorphism. The mineral assemblage consists predominantly of actinolite, plagioclase, hornblende, chlorite, quartz, calcite and opaques. The textures vary from spherulitic and plumose quench to intergranular basaltic texture. These metavolcanic suites are slightly evolved tholeiitic basalt-basaltic andesite in composition and endorse intra-oceanic Back-arc Basin Basalt (BABB) characteristics. Geochemically, the samples are slightly superchondritic $\left\{(\mathrm{La} / \mathrm{Yb})_{\mathrm{N}}=0.87-2.9\right\}$ and exhibits prominent negative $\mathrm{Nb}\left(\mathrm{Nb} / \mathrm{Nb}^{*}=0.41-0.71\right)$ and $\mathrm{Ti}(\mathrm{Ti} / \mathrm{Ti} *=0.79-0.93)$ anomaly in primitive mantle normalized trace element diagram. $\varepsilon N d(t)$ of the samples vary from -1.0 to 6.3 . $\varepsilon N d(t)$ versus ${ }^{87} \mathrm{Sr} /{ }^{86} \mathrm{Sr}$ diagram points to absence of crustal contamination in the genesis of the rocks. These geochemical and isotopic characters are consistent with subduction zone geochemical signatures and are formed at a relatively shallower depth by partial melting of an enriched source. The enrichment is attributed to fluid interaction by partial melting in the sub-arc mantle. The metavolcanic rocks yield an Sm-Nd age of 2.98 Ga. Overall, the metavolcanics from Kurrat-Badwar-Girar greenstone belt are consistent with their formation in a Mesoarchean subduction style geodynamic setting and are analogous to modern-style subduction phenomena.

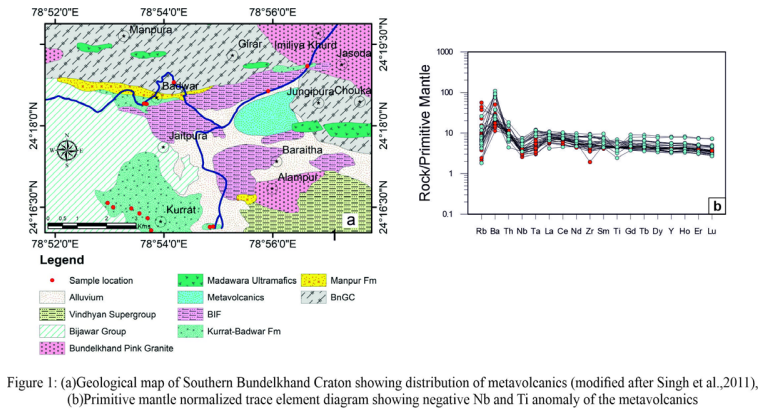

